\title{
Management of Root Knot Nematode on Tomato through Grafting Root Stock of Solanum sisymbriifolium
}

\author{
Suraj Baidya ${ }^{1 @}$, Ram Devi Timila ${ }^{1}$, Ram Bahadur KC ${ }^{2}$, Hira Kaji Manandhar ${ }^{1}$, Chetana Manandhar ${ }^{1}$ \\ ${ }^{1}$ Plant Pathology Division, NARC, Khumaltar, Lalitpur. @: suraj_baidya222@yahoo.co.in; RDT <rtimila@gmail.com>; HKM \\ <hirakaji@gmail.com>; CM <chetana.manandhar@gmail.com> \\ ${ }^{2}$ Nepal Agricultural Research Council, NARC, Singhdurbar, Plaza, Kathmandu. <rbkc05@gmail.com>
}

Received March 2016, Revised August 2016, Accepted October 2016; Published May 2017

Scientific Editors: Samudra Lal Joshi, Umesh Acharya

Copyright @2017 NARC. Permits unrestricted use, distribution and reproduction in any medium provided the original work is properly cited

\begin{abstract}
The root-knot nematodes (Meloidogyne spp) are difficult to manage once established in the field because of their wide host range, and soilborne nature. Thus, the aim of the present study was to examine the use of resistant root stock of wild brinjal (Solanum sisymbriifolium) to reduce the loss caused by the nematodes on tomato. For the management of root-knot nematodes, grafted plant with resistant root stock of the wild brinjal was tested under farmers' field conditions at Hemza of Kaski district. Grafted and non-grafted plants were produced in root-knot nematode-free soil. Around three week-old grafted and non-grafted tomato plants were transplanted in four different plastic tunnels where root-knot nematodes had been reported previously. The plants were planted in diagonal position to each other as a pair plot in $80 \times 60 \mathrm{~cm}^{2}$ spacing in an average of $20 \times 7 \mathrm{~m}^{2}$ plastic tunnels. Galling Index (GI) was recorded three times in five randomly selected plants in each plot at 60 days intervals. The first observation was recorded two months after transplanting. Total fruit yield was recorded from same plants. In the grafted plants, the root system was totally free from gall whereas in an average of 7.5 GI in $0-10$ scale was recorded in the non-grafted plants. Fruits were harvested from time to time and cumulated after final harvest to calculate the total fruit yield. It was estimated that on an average tomato fruit yield was significantly $(\mathrm{P}>0.05)$ increased by 37 percent in the grafted plants compared with the non-grafted plants. Grafting technology could be used effectively for cultivation of commonly grown varieties, which are susceptible to root-knot nematodes in disease prone areas. This can be used as an alternative technology for reducing the use of hazardous pesticides for enhancing commercial organic tomato production.
\end{abstract}

Keywords: Grafting, Root-knot nematodes, Tomato, Wild brinjal

सारांश

जरामा गाँठो बनाउने जुका (Root Knot Nematode) एक किसिमको परजीवी, जसले बिभिन्न बालीहरुका जरामा गाँठो बनाएर उत्पादनमा ह्रास पुच्याउछ । यो माटोजन्य जुकाले बेरै बालीहरुमा आक्रमण गर्न सक्ने हुँदा एक पटक खेतबारीमा यो जुका लागेपछि, पूर्ण रुपमा निर्मूल गर्न धेरै नै गाह्रो हुन्छ। कास्की जिल्लाको हेम्जामा गरिएको अध्ययनमा यस जुकाको आक्रमणले मात्र प्लाष्टिक घरमा खेती गरिने गोलभँडामा करिब ३०\% सम्म उत्पादन घटेको देखिन्छ। नेपालमा खेती गरिने प्राय सबै गोलभैंडाका जातहरुमा यस जुकाको आक्रमण भएको पाईन्छ । जुका नियन्त्रण गर्ने प्रविधि विकासको लागि जंगली भन्टामा (Solanum sisymbriifolium) गोलभ̈डडा कलमी गरी हेम्जामा जुकाको प्रकोप भएको कृषकको खेतबारी छनोट गरि जुका ब्यवस्थापन सम्बन्धी परीक्षण गरियो । कृषि अनुसन्धान केन्द्र मालेपाटन, पोखराको जुकाको प्रकोप नभएको नर्सरीबाट कलमी गरेको र नगरेको गोलभँडाको बोटहरु उत्पादन गरियो। करिव तीन हप्ता उमेर भएको बोटहरु चारवटा जुकाको प्रकोप भएको प्लाष्टिक घरमा ५० से.मी.लम्बाई र ६० से.मी. चौंडाईको फरक दुरीमा परीक्षण गरियो। बोट सारोको ६० दिन पछी प्रत्येक प्लाष्टिक घरमा $y-y$ वटा बोट छनोट गरी जराको गाँठोको तथ्यांड्ड (Galling Index, GI) मापन गरियो । त्यसैगरी ती बोटहरुबाट उत्पादन भएको गोलभँडाको तौल पनि संकलन गरियो। कलमी गरेको बोटको जरामा गाँठो देखिएन भने नगरिएको बोटमा औसत $\vartheta . y$ स्केलसम्म GI मापन गरियो। बोटहरुको उत्पादनमा कलमी नगरेको बोटको भन्दा कलमी बोटमा करिव ३७ प्रतिशतले उत्पादन बढेको पाईयो। तसर्थः आफुलाई अनुकूल वा मनपर्ने जातको गोलभ̈डामा जुका अवरोधक जंगली भन्टाको जरामा कलमी गरी यस परजीवी जुकालाई नियन्त्रण गर्न सकिने देखियो र साथ-साथै प्रांगारिक खेती प्रणालीमा हानिकारक विषादीको विकल्पको रुपमा पनि यस प्रविधिलाई विस्तार गर्न सकिने देखिन्छ।

\section{INTRODUCTION}

Plant parasitic nematodes are microscopic un-segmented worms, commonly described as filliform or thread-like multicellular invertebrates, one of the most harmful parasites of the vegetables in the world (Sasser and Freckman 1987, Giné et al 2016). Most agricultural fields are infested with at least one species of plant-parasitic nematodes (Luc et al 2005). Among the plant parasitic nematodes, root-knot nematodes (Meloidogyne spp) are the most commonly prevalent in the country. Once high 
population of Meloidogyne have developed in a field, it is virtually impossible to suppress and maintain population at sufficiently low level.

In tomato, root-knot nematodes are major biotic factor which is responsible for low yield (Giné et al 2016). It has been reported that on an average of 30 percent tomato fruits was reduced due to the nematodes in plastic tunnels at Hemja of Kaski district (PPD 2008). The problem of nematode has been increasing rapidly especially in year round tomato cultivation in plastic tunnel (PPD 2014). The intensive cropping of tomato in the plastic tunnels due to its high value is one of the barriers for the control of the nematode through crop rotation. Continuous mono-cropping is inevitable in vegetable production in indoor farming, reducing the yield and quality of products due to damages caused by nematodes and other soil borne diseases (Augustin et al 2002, Poffley 2003). Although nematodes are difficult to eradicate, it is essential to reduce the economic damage threshold for sustainable productivity. Preventing the development of nematodes problem may be more economical than managing the nematodes in the field. In many, chemical controls with granular, non-volatile nematicides are effective and are used extensively on a number of crops (Luc et al 2005). However, increasing concerns of the environmental risk posed by nematicides chemical control are unacceptable to the community. In an alternative to chemical pesticides, various strategies have been employed for the management of the nematodes around the world. Among them, root-knot nematodes in tomato are known to be effectively minimized by using grafted resistant root stock in susceptible cultivars (Luc et al 2005). Therefore, in present study, we tested whether the root-knot disease of tomato could be controlled by grafting resistant root stock of wild brinjal (Solanum sisymbriifolium) in the field condition of Nepal.

\section{MATERIALS AND METHODS}

\section{Identification of root-knot nematode species from tomato roots}

Galled roots were collected for identifying root-knot species from experimental plastic tunnels. Six different galled root samples of tomato from three different plastic tunnels, two from each tunnel were collected at Hemza of Kaski district. The galled roots were stained in cotton blue for removing body content of nematode. Five fresh adult females of Meloidogyne from each rooting system (altogether 30 females) were extracted and diagnosed the species. Stained females were dissected from root tissue by needle and kept in Petridish containing water. The posterior end of dissected females was cut off with scalpel on the Petridish cover and inner tissue was removed carefully by small soft brush. The cuticle was spread and mounted in a perineal pattern uppermost on slide with a drop of glycerol. The specimen mounted slides were examined under compound microscope to identify the species.

\section{Estimation of galling index and total yield}

Seedling of wild brinjal (Solanum sisymbriifolium) was produced for resistant root stock in nursery at Horticulture Research Station (HRS), Malepatan, Kaski District. Around 40 days-old wild brinjal plants were used as rootstock for grafting on the scion of 21 day-old tomato plants (hybrid: Thim-16) by cleft grafting technique. The grafted junction was covered with paraffin. The grafted plants were kept inside the grafting house immediately for $7-8$ days at $25 \pm 2^{\circ} \mathrm{C}$ in more than $90 \%$ relative humidity. The plants were transferred to the shade nursery house for hardening in open environment. After a week, the healthy grafted plants were selected for transplanting in plastic tunnel. Before transplanting, all the leaves grown below the grafted junction removed. In the meantime, the seedlings of Thim-16 were also produced in the nematode free nursery bed. Both the grafted and non-grafted tomato plants were transplanted in an area average of $20 \times 7 \mathrm{~m}^{2}$ in four different plastic tunnels, where the nematodes had been reported previously.

The experiments were carried out consequently for two years (2009 and 2010) at Hemza, Kaski district. During planting, the junction part was kept above the ground level to avoid root growth from/above the junction. In each tunnel, both grafted and non-grafted plants were transplanted diagonally to each other's in as pair plot in $80 \times 60 \mathrm{~cm}^{2}$ spacing. In the tunnels, remaining all the required inputs (fertilizers, irrigation, staking, weeding, nutrition, and foliar pesticides) was equally provided to all plants. Galling index was recorded three times in five randomly selected plants in each plot at 60 days intervals. Gall index was recorded in 0-10 scale as described by Bridge and Page 1980 (Table 1). The first observation was recorded two months after transplanting. Total fruit yield was recorded from same plants. Fruits were harvested from time to time and cumulated the fruit yield after final harvest to calculate the total fruit yield. The total yield difference was calculated between the grafted and non-grafted plants in T-test at 0.05 level in M-STAT. 
Table 1. Galling index with rating description

\begin{tabular}{ccl}
$\begin{array}{c}\text { Galling index system } \\
(\mathbf{0 - 1 0})\end{array}$ & $\begin{array}{c}\text { Percentage of total root } \\
\text { system galled }\end{array}$ & \multicolumn{1}{c}{ Explanation of rating } \\
\hline 0 & 0 & Complete and healthy root system, no infection \\
1 & 10 & Very few small galls can only be detected upon close examination \\
2 & 20 & Small galls/knot only but clearly visible main root clean \\
3 & 30 & Some larger knot visible, main root clean \\
4 & 40 & Larger knot predominate but main root clean \\
5 & 50 & Ko\% of root infested, knotting on some main roots, reduced root system \\
6 & 60 & Majority of main roots knotted \\
7 & 70 & All main roots, including tap root, knotted, and few clean root visible \\
8 & 80 & All roots severely knotted, and plant usually dying \\
9 & 90 & All roots severely knotted, no root system, and plants usually dead. \\
\hline
\end{tabular}

\section{RESULTS}

In our observation from the 30 fresh female root-knot nematodes collected from galling tomato root, fourteen patterns matches to the structure of $M$. incognita and twelve to $M$. javanica. Four patterns could not be diagnosed. These two species were found either together or alone in tomato growing plastic tunnels (Table 2). Out of six different root systems, two root systems had single species of $M$. incognita and rest four samples had both species. Four perineal pattern of female could not diagnose due to unclear view.

Table 2. Species identification of root-knot nematodes collected from the root samples of Hemza, Kaski district

\begin{tabular}{lcccl}
\hline Sample lot & No. of female & Diagnosed species & Number & Remarks \\
\hline 1 & 5 & Meloidogyne incognita & 5 & - \\
2 & 5 & M. incognita & 2 & 1 sample not diagnosed \\
& & M. javanica & 2 & \\
3 & 5 & M. javanica & 3 & - \\
4 & 5 & M. incognita & 2 & 2 samples not diagnosed \\
5 & 5 & M. incognita & 3 & 1 savanica \\
\multirow{2}{*}{6} & M. incognita & 3 & 1 & \\
& 5 & M. incognita & 1 & - \\
\hline Total & $\mathbf{3 0}$ & & 4 & \\
\hline
\end{tabular}

The total fruit yield of grafted plants was significantly higher (37\%) than of the non-grafted plants (Table 3). Yield increased was recorded by $2.9 \mathrm{~kg}$ per in grafted plant than non-grafted plant. The results showed that the root system of grafted plants was totally free from galls of nematode infection whereas in average, 7.5 galling index (GI) was recorded in non-grafted plants. Knots were found in all main roots, including tap root and their size was also big with very few clean roots. The grafted plant survived two months more (11 months) compared with non-grafted ( 9 months). It was due to the fact the root system of the grafted plants was free from nematode infection with vigor root system. In initial three months, yield performance was not vary on grafted and non-grafted, but later the yield was significantly increased on the grafted plant (Figure 1).

Table 3. Fruit yield and galling index estimated in grafted and non-grafted tomato plant cultivated in root-knot nematode infested plastic tunnel at Hemza, Kaski district

\begin{tabular}{|c|c|c|c|c|}
\hline \multirow{2}{*}{ Parameter } & \multicolumn{2}{|c|}{ Yield per plant $(\mathrm{kg})$} & \multicolumn{2}{|c|}{ Galling index $(0-10)$} \\
\hline & Year 2009 & Year 2010 & Year 2009 & Year 2010 \\
\hline Grafted $^{1}$ & $12.064( \pm 1.39)^{5}$ & $9.41( \pm 1.39)^{5}$ & 0 & 0 \\
\hline Non grafted $^{1}$ & $8.98( \pm 0.68)^{5}$ & $6.78( \pm 0.68)^{5}$ & 8 & 7 \\
\hline Yield increase over non-grafted ${ }^{2}$ & 3.104 & 2.63 & - & - \\
\hline$\%$ increase $^{3,4}$ & $34.64 * *$ & $38.79 * *$ & - & - \\
\hline Average & \multicolumn{2}{|c|}{36.72} & \multicolumn{2}{|c|}{7.5} \\
\hline
\end{tabular}




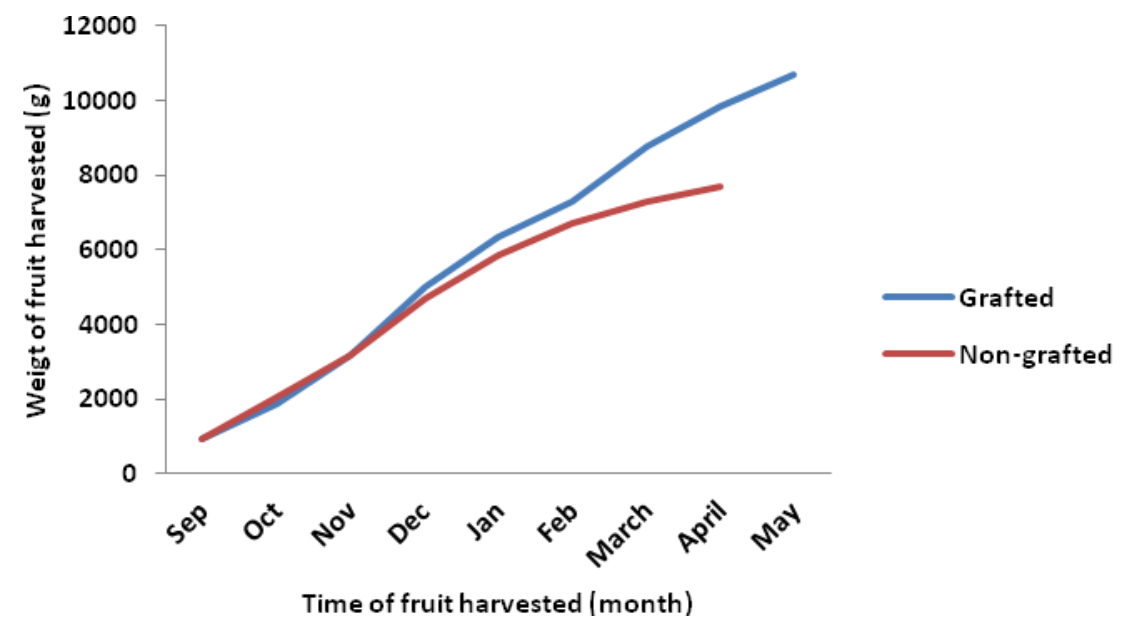

Figure 1. Comparison of tomato fruits harvesting period in grafted and non-grafted plants of plastic tunnel at Hemza, Kaski district

\section{DISCUSSION}

Root-knot nematodes are common and destructive plant parasitic nematodes which have wide host range and can significant yield loss in many crops (Giné et al 2016). They are polyphagous and reported in many crops such as tomato, brinjal, okra, potato, chilly, radish, carrot, onion, cabbage, cauliflower, lettuce, chickpea, broad bean, cowpea, cucumber, pumpkin and various gourds from plains to high hills of the country (Amatya and Shrestha 1969, PPD 2009). More than 90 species of Meloidogyne have been reported from different parts of world, but only four species such as M. javanica, M. arenaria, M. incognita and M. hapla have been reported in Nepal (Manandhar and Amatya 1988, Mathur et al 1989, Netscher and Sikora 2005). Study of posterior cuticular pattern the so-called perineal pattern of female root-knot nematode is one of the common practices to identify the species. In our observation, two different nematode species $M$. incognita and $M$. javanica were found in the tested area. Rana and Ali (1992) have also reported more than one species of Meloidogyne in a single plant. In addition, they reported M. incognita was most common species (56\%) followed by M. arenaria (37\%) and M. javanica (23\%) from the field of winter vegetables crops at Chitwan district.

Farmers are usually cultivating susceptible tomato cultivar as mono crop for several years, which density of nematodes and causing severe damage of crops. However, farmers are not ready or willing to replace the cultivars because of market demand on fruit quality. Management of the nematodes has been essential considering the substantial loss of the crop yield and quality. Grafting in many countries have been proved to be an alternative management approach, especially where temperature does not affect the genes controlling resistance (Netscher and Sikora 2005). Three species of Solanum, namely $S$. sisymbriifolium, S. torvum and S. toxicarium were used as root stocks, not only reduced galling on tomato, but also reduced bacterial wilt of aubergine caused by Ralstonia solanacearum (Mian et al 1995). We also found that the use of root of wild brinjal (S. sisymbriifolium) as resistant root stock against root-knot nematodes could effectively manage the nematodes in tomato growing area. In addition, life span of plant was also increased than non-grafted plant due to its vigorous root system. According the tomato growers, the tomato fruits of grafted plants at the end of the harvesting stage could also obtain high price in the market because of production has already been terminated from the most normal tomato plants.

The total fruit yield of grafted plant was found significantly $(\mathrm{P}<0.05)$ higher than of the non-grafted plants. Luc et al (2005) also found that the yield of grafted plants was increased by 50 and 30 percent at the beginning and at the end of harvest respectively as compared with the non-grafted plants. Also, it was reported that the yield increase was directly related to the number of fruits. The number of fruits increased by 28 and 58 percent in grafted tomato cultivar; Baluroi and Prelane, respectively comparing with non-grafted plants (Vuruskan and Yanmaz 1990). The increased in the fruit yield was due to suppression of nematode population in the field planted with the grafted plants. The grafted plants might have suppressed the nematodes population due to differences in rate of penetration, multiplication and death. This might support to keep the nematode population in the field minimum level for the next season. According to Lee (1994), the increased yield of grafted 
plants is also believed to be due to enhanced water and mineral uptake. Hence, host plant resistance has become an important strategy in the management of plant parasitic nematodes.

\section{CONCLUSION}

Grafting is one of the most effective and innovative techniques for the management of root-knot nematodes. Grafted plants not only reduce the population of nematodes in the fields also increased the fruit yield with longer survivability of tomato plants than the non-grafted plants. The grafting technique for tomato production in plastic tunnel is economically benefited to the growers for long term low-input sustainable agriculture. It can also be taken as an alternative technology for reducing the use of hazardous pesticides in organic tomato production. In addition, the grafting technology could be used effectively for cultivation of commonly grown varieties, which are susceptible to root-knot nematode in disease prone areas.

\section{ACKNOWLEDGEMENTS}

The authors are thankful to Mr CK Timalsina, Regional Agriculture Research Station, Lumle and Mr. CP Lalchan, Horticulture Research Station, Malepatan for producing grafted and non-grafted plants on time. We would like to acknowledge farmers of Hemza, Kaski district on their active participation and co-operation during field experiment.

\section{REFERENCES}

Amatya P and M Shrestha. 1969. Preliminary Survey of Plant Parasitic Nematodes in Nepal. Nepalese Journal of Agriculture. 4:17-27.

Augustin B, V Graf and N Laun. 2002. Temperature influencing efficiency of grafted tomato cultivars against root-knot nematode (Meloidogyne arenaria) and corky root (Pyrenochaeta lycopersici) Nematologia Mediterrannea 109:371-383.

Bridge J and S L J Page. 1980. Estimation of root knot nematode infestation level on roots using a rating chart. Tropical Pest Management 26: 296-298.

Giné A, M Carrasquilla, M Martínez-Alonso, N Gaju Francisco and J Sorribas. 2016. Characterization of Soil Suppressiveness to RootKnot Nematodes in Organic Horticulture in Plastic Greenhouse, Front. Plant Sci. pp.1-17.

Lee JM. 1994. Cultivation of grafted vegetables In: Current status, grafting methods and benefits. Horticulture Science, 29: 235-239

Luc M, J Bridge and RA Sikora. 2005. Reflection on Nematology in Subtropical and Tropical Agriculture. In: Plant Parasitic Nematodes in Subtropical and Tropical Agriculture (Luc M, RA Sikora, J Bridge ed). CABI Bioscience, Egham, UK, 2005: xi-xvii.

Netcher C and RA Sikora. 2005. Nematode Parasites of Vegetables. In: Plant Parasitic Nematodes in Subtropical and Tropical Agriculture (Luc M, RA Sikora, J Bridge ed). CABI Bioscience, Egham, UK, 2005:325-356.

Manandhar HK and P Amatya. 1988. Identification of species and races of root-knot nematodes at NGLIP, Rampur, Chitwan. Paper presented at the working group meeting for winter grain legumes. National Wheat Development Programme, Bhairahawa, Nepal, September 7-8, 1988.

Mathur A, P Amatya, K Shrestha and HK Manandhar. 1989. Plant Disease and Seed Production and Seed Health testing in Nepal. Proceedings of the first HMG/DANIDA/FAO training course in seed health testing techniques, pp.53-58.

Mian IH, R Akhter and MN Islam. 1995. Resistance of tomato and wild Solanum to Meloidogyne incognita. Bulletin of the Institute of tropical Agriculture, Kyushu University 18: 33-40.

Poffley M 2003. Grafting tomatoes for bacterial wilt control. Agnote, 603, No. B40.

Rana H B and Z Ali. 1992. Incidence of Root knot nematodes on vegetables and legumes in Chitwan. Institute of Agriculture and Animal Science (IAAS) 13:117-119.

Sasser J and D Freckman. 1987. A world perspective on nematology: the role of the society. In: Vistas on Nematology (JA Veech and DW Dickson eds) (Hyattsville, MD: Society of Nematologists), 7-14.

Vuruskan MA and R Yanmaz. 1990. Effects of different grafting methods on the success of grafting and yield of eggplant/tomato graft combination. Acta Horticulturae Protected Cultivation of Vegetables, Turkey. 287:405-409.

PPD. 2008. Annual Report 2006/07. Plant Pathology Division, NARC. Khumalar, Lalitpur.

PPD. 2009. Annual Report 2007/08. Plant Pathology Division, NARC. Khumalar, Lalitpur.

PPD. 2014. Annual Report 2007/08(2013/14) (BN Mahto, S Baidya, RD Timila, S Joshi and B Pant, eds). Plant Pathology Division, NARC. Khumalar, Lalitpur. 